\title{
Contributions of agroforestry practice in Ondo State, Nigeria, to environmental sustainability and sustainable agricultural production
}

\author{
Victor Ajibola Adekunle
}

Federal University of Technology, Department of Forestry and Wood Technology, Akure, Nigeria

\begin{abstract}
Man is using more energy, land, water, and natural resources than ever before. Population increase also leads to increasing food insecurity. In view of this, the contributions of agroforestry (AF) to enhancing food security and environmental conservation were assessed. The study was carried out in Ondo state, Nigeria, situated in the tropical rainforest ecological zone. Data were collected with pre-tested questionnaires administered to 300 farmers -household heads, randomly selected from four Local Government Areas (LGAs). Information was gathered on farmers' awareness of and involvement in AF systems, willingness to plant, retain or take care of trees planted, farm location and sizes, tree species commonly retained/planted on farmland, major causes of deforestation, extension education in AF and other information relevant to the study. Data were analyzed using a descriptive statistics and $\chi^{2}$ model. Results revealed that the primary occupation of the majority of the respondents $(80 \%)$ is farming. Land is mainly obtained through lease from landowners $(52 \%)$. This is followed by those who inherited land $(26 \%)$. Very few respondents $(6 \%)$ have their farms on government land through AF (Approved Taungya System). Most farmers $(67 \%)$ were willing to plant, retain and take care of trees on their farmland to provide shade for crops, for edible fruits, timber and firewood, erosion and leaching control, biodiversity conservation, reduction of global warming, and increased crop yield. Average yearly crop yield (cassava and maize) from AF farms was $750 \mathrm{~kg} / \mathrm{ha}$ against $630 \mathrm{~kg} / \mathrm{ha}$ for non-AF farms. Agroforestry is a means of increasing food production and at the same time, it makes wood available to rural dwellers. However, there is a need to improve both formal and informal AF education among the rural communities for agroforestry to become more widely accepted by local populations.
\end{abstract}

Key words: agroforestry, Taungya, forest reserves, savanna woodland

\section{Introduction}

Climate change, food insecurity, and loss of genetic resources are attracting global concern today. Atolagbe (2002) reported that man's life is unimaginable without the natural environment to supply him with his basic needs such as air to breathe, water to drink, food to eat, solid minerals, plants and animals. The most insidious and substan- 
tial environmental threats to human well-being and survival are man-induced changes to the world's climate. The gradual increase in the earth's temperature is referred to as global warming. Global warming is caused by several greenhouse gases, of which carbon dioxide $\left(\mathrm{CO}_{2}\right)$, methane $\left(\mathrm{CH}_{4}\right)$ and nitrous oxide $\left(\mathrm{N}_{2} \mathrm{O}\right)$ are the most important (Ranasingbe and Abayasiri, 2008; IPCC, 2007).

$\mathrm{CO}_{2}$ comes mainly from the burning of fossil fuels by industries and vehicular transportation, from burning biomass and massive increases in deforestation. Okojie (1996) reported that the devastation and destruction of the environment could cause pollution, deep and extensive damage to the earth's crust, destruction of vegetation and wildlife and also continued increase in $\mathrm{CO}_{2}$ emission into the atmosphere. Almost all human activities can directly be linked to environmental degradation. In this respect, the ecological, economical and environmental roles of tropical rainforests and savanna woodlands to rural dwellers and national development are negatively affected. The environmental role of natural and planted trees includes air and water purification, water flow regulation, detoxification and decomposition of wastes (UNEP, 2006; Adekunle, 2006), carbon sequestration, climate stabilization and creation of microclimates, and moderation of temperature extremes. In addition, when trees are planted, they serve as windbreaks (as in shelterbelts) but also contribute to environmental beautification (Adekunle et al., 2005: Daily, I997).

Deforestation was defined by Achard et al. (2002) as "the conversion from forest to non-forest lands" while forest degradations are the "processes within the forest that could lead to a significant reduction in either the density or proportion of forest cover." The increasing size of the world population has led to a tremendous rise in the demand for living space, food and energy. As a result, more forestlands are now converted to farmland and other uses than ever before. In addition, the present heavy dependence on fuelwood by rural people and urban poor in developing countries like Nigeria has led to increased deforestation. Deforestation has grave consequences that include climate change, desert encroachment, soil erosion, sand dune formation, landslides, flooding and biodiversity loss (McNally et al., 2002; Salami, 1998). Other causes of deforestation are unemployment, habitat destruction, scarcity of land, over exploitation of forest resources, change in land use, pollution and lack of emphasis on forest conservation (Adekunle, 2005). Achard et al. (2002) estimated the mean annual deforestation in humid tropical forest of Africa to be as high as $0.85 \pm 0.30 \times 10^{6}$ hectares.

The traditional system of African farming (shifting cultivation and fallow) was formerly sustainable. As populations have continued to increase, these methods of farming have become unsustainable. There is more demand for food, leading to more pressure on forestlands and forest products. Moreover, recent increases in urbanization and infrastructural development has further increased pressure on forestland. As a result, fallow periods are shortened, there is reduction in productive capacity of the soil and decrease in crop yields.

In view of the above, agroforestry i.e. land use systems and practices where woody perennials (trees, shrubs, bamboo) are deliberately grown in combination with agricul- 
tural crops and/or animals in some form of spatial arrangement or temporary sequence (Lundgren, 1982 \& 1987) can help in solving food shortage and environmental problems. Apart from providing wood, food and/or animal products, the integration of trees in the farming system could go a long way to help ameliorate environmental problems: specifically by creating microclimates favourable for crop growing, and enhancing the recycling of minerals to provide a more complete ground cover which could help to protect the soil from erosion and moderate extreme temperatures (Adedire, 1999 and 2004). The goal of sustainable food production and environmental conservation could be achieved with more widespread adoption of AF. In this respect, Leakey (1996) wants agroforestry to be reconsidered as a dynamic, ecologically-based, natural resource management system. It is against this background that this study aimed at examining the possible contributions of agroforestry to enhancing environmental sustainability and sustainable agricultural production in Ondo state, Nigeria. This was achieved with the use of a structured questionnaire administered to 300 household heads randomly selected from four Local Government Areas (LGAs) in Ondo state, and focus group discussions (FGD) with agroforestry farmers in the study locations to validate the questionnaires' results.

\section{Methodology}

The study area: the present study was carried out in Ondo State, Nigeria. The State was created on 3 rd February 1976 as one of the states from the former Western state. It is an agrarian state with 18 LGAs. Four LGAs (Odigbo, Akoko, Idanre and Akure South) were purposively selected for this study. These LGAs are situated within the tropical rainforest ecosystem where farming activities are quite prominent. Three rural communities were randomly selected from each of the four LGAs and 25 household heads were also randomly selected from each of the communities. The questionnaire was administered to a total of 75 farmers in each of the four selected LGAs. All selected farmers are household heads. The total number of questionnaires administered and retrieved thus was 300 . The questionnaire was designed to gather information on farmers' awareness and adoption of AF systems, their willingness to plant trees, retain trees on farmland during cultivation or take care of those planted. Information was also collected on farm location and farm size(s), tree species commonly retained/planted on farmland, major causes of deforestation and other vital information relevant to the study. All questionnaires were completed and retrieved on site because most respondents had no formal education. Focus Group Discussions were held with agroforestry farmers in each of the selected locations to validate and complement the information collected with the questionnaires.

Data obtained were analyzed using descriptive statistics that include the use of frequency distributions, means and percentages. Chi-square $\left(\chi^{2}\right)$ was used to test for the presence of associations in the variables obtained. Also, one-way analysis of variance (ANOVA) was employed to test for the presence of significant difference in respondents' ages, family sizes, major occupations, farm sizes, sources of farmland and level of adoption of AF. Where significant differences occurred, means separation was carried out with Fisher's Least Significant Difference (LSD). Student t-test was used to verify the presence 
of significant differences between respondents' gender, proportion of those aware of agroforestry practices and those who are not aware, and average annual income per hectare from AF farms and non-AF farms as indicated by respondents, in order reveal the contributions of AF practices to rural livelihood.

\section{Results and discussion}

Results

Table I shows the gender, marital status, age, family size and educational level of the respondents. It can be seen that $95 \%, 93 \%, 79 \%$ and $85 \%$ were male in Odigbo, Akoko, Idanre and Akure LGAs, respectively, leaving only $12 \%$ of women as AF farmers among the respondents. The results of the t-test show a significant difference $(\mathrm{P}<0.05, \mathrm{df}=3)$ in gender distribution among the respondents. The proportion of males is significantly higher than that of females. The majority of respondents are married (76\%) with only $4 \%$ being single. It was found that divorcees and widows/widowers are also involved in farming activities in the study locations. The $\chi^{2}$ results confirm that the participation of respondents in AF farming does not depend on marital status in study locations.

\begin{tabular}{|c|c|c|c|c|c|}
\hline \multirow[t]{2}{*}{ VARIABLES } & \multicolumn{5}{|c|}{ LOCATIONS (LGAs) } \\
\hline & Odigbo & Akoko & Idanre & Akure & Total \\
\hline \multicolumn{6}{|c|}{ Gender respondents } \\
\hline Male & $7 \mathrm{I}(95 \%)$ & $70(93 \%)$ & $59(79 \%)$ & $64(85 \%)$ & $264(88 \% \star)$ \\
\hline Female & $4(5 \%)$ & $5(7 \%)$ & I6 (2I\%) & II (I5\%) & $36(12 \%)$ \\
\hline t-test results & \multicolumn{5}{|c|}{$\begin{array}{l}\mathrm{t} \text {-calculated }=\mathrm{II} .44, \mathrm{t} \text {-tabulated }(\mathrm{df}=3)=3.18, \mathrm{P}=0.00 \mathrm{I},{ }^{\star} \text { significant } \\
(\mathrm{P}<0.05)\end{array}$} \\
\hline \multicolumn{6}{|l|}{ Marital Status } \\
\hline Married & $5 \mathrm{I}(68 \%)$ & $59(79 \%)$ & $60(80 \%)$ & $58(77 \%)$ & $228(76 \%)$ \\
\hline Single & $3(4 \%)$ & $2(3 \%)$ & $3(4 \%)$ & $5(7 \%)$ & I3 (4\%) \\
\hline Divorcee & $8(\mathrm{II} \%)$ & $5(7 \%)$ & 9 ( $12 \%)$ & $6(8 \%)$ & $28(9 \%)$ \\
\hline Widow/Widower & $13(17 \%)$ & 9 (I2) & $3(4 \%)$ & $6(8 \%)$ & 3I (II\%) \\
\hline$\chi^{2}$ results & \multicolumn{5}{|c|}{$\begin{array}{l}\chi^{2} \text { calculated }=\mathrm{II} .56, \chi^{2} \text { tabulated }(\mathrm{df}-6)=\mathrm{I} 2.59 \\
\text { not significant }(\mathrm{P}>0.05)\end{array}$} \\
\hline \multicolumn{6}{|c|}{ Age of respondents } \\
\hline$<30$ years & $6(8 \%)$ & $5(7 \%)$ & $8(\mathrm{II} \%)$ & Io (13\%) & $29(10 \%)^{a}$ \\
\hline $3 I-40$ & $17(23 \%)$ & I3 (I7\%) & 2I ( $28 \%)$ & I4 (I9\%) & $65(23 \%)^{b}$ \\
\hline $4 I-50$ & $37(49 \%)$ & $46(6 \mathrm{r} \%)$ & $38(51 \%)$ & $48(64 \%)$ & $169(56 \%)^{c}$ \\
\hline$>50$ & $15(20 \%)$ & II (15\%) & $10(13 \%)$ & $3(4 \%)$ & $39(13 \%)^{d}$ \\
\hline ANOVA results & \multicolumn{5}{|c|}{$\begin{array}{l}\text { F- calculated }=58.60, F-\text { tabulated }(d f-3,12)=3.49, \\
\text { significant }(P<0.05)\end{array}$} \\
\hline
\end{tabular}




\begin{tabular}{|c|c|c|c|c|c|}
\hline \multirow{2}{*}{$\begin{array}{l}\begin{array}{l}\text { Family size } \\
\text { (no. of persons) }\end{array} \\
\mathrm{I}-4 \\
\end{array}$} & \multirow[b]{2}{*}{ I8 (24\%) } & \multirow[b]{2}{*}{ I6 (2I\%) } & \multirow[b]{2}{*}{ I9 (25\%) } & \multirow[b]{2}{*}{ I2 (16\%) } & \multirow[b]{2}{*}{$65(22 \%)^{a}$} \\
\hline & & & & & \\
\hline $5-7$ & $33(44 \%)$ & $29(39 \%)$ & $4 \mathrm{I}(55 \%)$ & $38(51 \%)$ & I4I $(47 \%)^{b}$ \\
\hline $8-10$ & II (I5\%) & $14(19 \%)$ & II (I5\%) & I6 (2I\%) & $52(17 \%)^{c}$ \\
\hline$>$ Io; & $13(17 \%)$ & I6 (2I\%) & $4(5 \%)$ & $9(12 \%)$ & $42(14 \%)^{d}$ \\
\hline ANOVA results & \multicolumn{5}{|c|}{$\begin{array}{l}\text { F- calculated }=28.58, F-\text { tabulated }(\mathrm{df}-3, \mathrm{I2})=3.49 \\
\text { significant }(\mathrm{P}<0.05)\end{array}$} \\
\hline \multicolumn{6}{|l|}{ Education status } \\
\hline No formal education & $56(75 \%)$ & $59(79 \%)$ & $6 \mathrm{I}(8 \mathrm{r} \%)$ & $54(72 \%)$ & $230(77 \%)$ \\
\hline Primary education & $15(20 \%)$ & IO ( $13 \%)$ & $8(\mathrm{II} \%)$ & $17(23 \%)$ & $50(17 \%)$ \\
\hline Secondary education & $3(4 \%)$ & $2(3 \%)$ & $4(5 \%)$ & I (I\%) & Io $(3 \%)$ \\
\hline Tertiary education & $\mathrm{I}(\mathrm{I} \%)$ & $4(5 \%)$ & $2(3 \%)$ & $3(4 \%)$ & Io (3\%) \\
\hline$\chi^{2}$ results & \multicolumn{5}{|c|}{$\begin{array}{l}\chi^{2} \text { calculated }=8.74, \chi^{2} \text { tabulated }(\mathrm{df}-6)=\mathrm{I} 2.59, \\
\text { not significant }(\mathrm{P}<0.05)\end{array}$} \\
\hline
\end{tabular}

Note: values followed with similar superscripts are not significantly different.

Table 1: Gender, marital status, age, family size and educational levels of AF farmers in Ondo State, Nigeria.

Most farmers ( $56 \%$ ) were found in the age group $4 \mathrm{I}-50$ years whereas the leastrepresented age group was $<30$ years. The highest proportion of respondents has a large family: $47 \%$ has a family size of between 5 and 7 . As for education status, $77 \%$ have no formal education. The level of education will directly affect one's ability to adapt to change and to accept new ideas. Only $3 \%$ of respondents had secondary or tertiary education. This set of people are involved in farming because of the unemployment problem in the country. It is almost certain that as soon as they secure a job in the city, they will abandon the farm. The $\chi^{2}$ test results (significant at $\mathrm{p}<0.05$ ) reveal that the educational level of the respondents correlated highly with farming. Farming is the primary occupation of the majority of respondents in the study area. However, there is no significant difference ( $p>0.05$ ) between the level of education of these respondents and the study locations as shown by $\chi^{2}$ results in table $\mathrm{I}$. The level of education of respondents therefore does not depend on location. Results follow the same trend in the four selected locations. Generally, the highest proportion of farmers in rural communities lack a formal education. The results of the one-way analysis of variance indicate the presence of significant differences $(p<0.05)$ in age and family size distribution of the respondents. This shows that there is a wide variation in distribution of respondents over different age groups and family sizes.

It was observed that the primary occupation of the majority $(77 \%)$ of the respondents is farming (table 2). This is followed by the trades (10\%) (i.e. bricklayers, carpenters, blacksmiths, carvers or motor mechanics). ANOVA and LSD results show a very significant difference ( $p>0.5$ ). This confirms that farming is the commonest primary occupation of respondents in the selected locations. Farming is very labour-intensive and tedious 
because it is done manually in developing countries. Families tend to be large to provide sufficient labour to work the land. In the study areas farming is regarded as man's job which is why there are more men (adults) than women in farming and AF practices.

\begin{tabular}{|c|c|c|c|c|c|}
\hline \multirow[t]{2}{*}{ VARIABLES } & \multicolumn{5}{|c|}{ LOCATIONS (LGAS) } \\
\hline & Odigbo & Akoko & Idanre & Akure & Total \\
\hline \multicolumn{6}{|l|}{$\begin{array}{l}\text { Major occupation } \\
\text { of respondents }\end{array}$} \\
\hline Farming & $54(72 \%)$ & $59(79 \%)$ & 6I (8I\%) & $57(76 \%)$ & $23 \mathrm{I}(77 \%)^{\mathrm{a}}$ \\
\hline Trading & 9 (I2\%) & $2(3 \%)$ & $5(7 \%)$ & $2(3 \%)$ & I8 $(6 \%)^{b}$ \\
\hline Craftsman & $5(7 \%)$ & 9 (II\%) & $4(5 \%)$ & I3 (17\%) & $31(10 \%)^{c}$ \\
\hline Civil servants & $7(9 \%)$ & $5(7 \%)$ & $5(7 \%)$ & $3(4 \%)$ & $20(7 \%)^{d}$ \\
\hline ANOVA results & \multicolumn{5}{|c|}{$\begin{array}{l}\text { F- calculated }=274.65, F-\text { tabulated }(\mathrm{df}-3, \mathrm{I2})=3.49 \text {, } \\
\text { significant }(\mathrm{P}<0.05)\end{array}$} \\
\hline \multicolumn{6}{|l|}{ Farm size } \\
\hline$<$ I ha & $30(40 \%)$ & $28(37 \%)$ & $23(31 \%)$ & $35(46 \%)$ & II6 $(38 \%)^{2}$ \\
\hline I - 2 ha & $35(47 \%)$ & $3 \mathrm{I}(4 \mathrm{I} \%)$ & 4I ( $54 \%)$ & $27(36 \%)$ & $134(45 \%)^{b}$ \\
\hline $3-4$ ha & $4(5 \%)$ & II ( $15 \%)$ & 9 (12\%) & II (I5\%) & $35(12 \%)^{c}$ \\
\hline$>4$ ha & $6(8 \%)$ & $5(7 \%)$ & $2(3 \%)$ & $2(3 \%)$ & $15(5 \%)^{d}$ \\
\hline ANOVA results & \multicolumn{5}{|c|}{$\begin{array}{l}\text { F- calculated }=45.75, F-\text { tabulated }(d f-3,12)=3.49, \\
\text { significant }(P<0.05)\end{array}$} \\
\hline \multicolumn{6}{|l|}{ Source of farmland } \\
\hline Inheritance & $23(31 \%)$ & $28(38 \%)$ & I2 (I6\%) & $15(20 \%)$ & $78(26 \%)^{a}$ \\
\hline Lease & $42(56 \%)$ & $34(45 \%)$ & $39(53 \%)$ & $4 \mathrm{I}(55 \%)$ & $156(52 \%)^{b}$ \\
\hline Purchase & IO (13\%) & I2 (I6\%) & $2 \mathrm{I}(28 \%)$ & $17(22 \%)$ & $60(20 \%)^{c}$ \\
\hline Government land & $\circ(0 \%)$ & $\mathrm{I}(\mathrm{I} \%)$ & $3(4 \%)$ & $2(3 \%)$ & $6(2 \%)^{d}$ \\
\hline ANOVA results & \multicolumn{5}{|c|}{ F- calculated $=4 \mathrm{I} .57, \mathrm{~F}-$ tabulated $(\mathrm{df}-3, \mathrm{I} 2)=3.49$, significant $(\mathrm{P}<0.05$} \\
\hline
\end{tabular}

Note: values followed with similar letter are not significantly different.

Table 2: Awareness of agroforestry practices among respondents.*

There is variation in the sources of land used for farming by the respondents. The highest proportion $(52 \%)$ claimed that they obtained farmland through lease arrangements. This is followed by those who inherited land from their forefathers. The latter farmlands are usually very small in size as an initial parcel of land is normally shared among many children. Very few indicated that they use government land (6\%).

The total size of respondents' farmland varied from I to 4 ha with the majority ( $45 \%)$ having a farm size of between $I$ and 2 ha. Thirty-eight percent of respondents have a farm size of less than one hectare. This group of people can only produce what they need for 
their own family with little or no extra being offered for sale. It was observed that $15 \%$ of respondents have a landholding that is more than four hectares. It is common for these farmlands to be divided into small sections referred to as plots. Plots are then usually about one kilometer apart as claimed by respondents. ANOVA results show that there are significant differences ( $\mathrm{p}<0.05$ ) in respondents' farm size and also in the respective sources of their farmland.

Table 3 shows the level of awareness of AF practices in the localities. In Odigbo, $23 \%$ of the 75 respondents, claimed not to be aware of any AF practice while only $7 \%$ confirmed their ignorance of AF practices in Idanre. In general, a very high proportion of the respondents $(85 \%)$ are fully aware of the potential of agroforestry (e.g. increase in food production and environmental conservation). The results of the t-test (table 3 ) reveal a significant difference $(\mathrm{p}<0.05)$ in the proportion of those aware of AF practices and those not aware.

\begin{tabular}{l|l|l|l|l}
\hline Locations & No & $\%$ & Yes & $\%$ \\
\hline Odigbo & I7 & 23 & 58 & 77 \\
\hline Akoko & I2 & I6 & 63 & 84 \\
\hline Idanre & 5 & 7 & 70 & 93 \\
\hline Akure & II & I5 & 64 & 85 \\
\hline Total & 45 & I5 & 255 & 85 \\
\hline t-test results & $\begin{array}{l}\star \text { t-calculated }=\text { I0.66, } \\
\text { t-tabulated }(\mathrm{df}-3)=3.18, \mathrm{P}=0.002, \text { significant }(\mathrm{p}<0.05)\end{array}$ \\
\hline
\end{tabular}

Table 3: Awareness of agroforestry practices among respondents.*

The level of adoption of agroforestry systems by respondents in each of the communities is presented in Table 4. Deliberately retaining trees on farmland during land preparation was the most common AF system in the study area as indicated in this table. It was found that a greater proportion ( $80 \%$ in Odigbo, $59 \%$ in Akoko, $21 \%$ in Idanre and $76 \%$ in Akure) of respondents are willing to retain different species of trees on their farm than those who are not ready to. According to these farmers, these species are retained to provide shade for crops, control soil erosion, and to supply edible fruits, timber, and herbs. Only a few farmers practice alley cropping. Most of them complained that the technology of alley cropping is not clear to them. Farmers with farmland located in different places have the opportunity to combine several AF systems. The scarcity of land prevented the majority of respondents from having woodlots for timber or woodfull production, while a sizeable number (60\%) cultivated cocoa agroforests. A cocoa agroforest is the combination of tree species with cocoa. This practice is common at Idanre where their major cash crop is cocoa. Results of the one-way analysis of variance reveal that there are significant differences $(p<0.05)$ in the number of respondents adopting each of the agroforestry systems. LSD results show that there are no significant differences ( $p>0.05$ ) between the presence of woodlots and level of adoption of alley cropping in the study area (Table 4). 


\begin{tabular}{|c|c|c|c|c|c|c|c|c|}
\hline \multirow[t]{2}{*}{ Type of AF } & \multicolumn{8}{|c|}{ Locations and frequency } \\
\hline & Odigbo & $\%$ & Akoko & $\%$ & Idanre & $\%$ & Akure & $\%$ \\
\hline Approved taungya & 25 & 33 & 33 & 44 & 20 & 27 & 25 & $33^{\mathrm{a}}$ \\
\hline $\begin{array}{l}\text { Retaining tress } \\
\text { on farmlands }\end{array}$ & 60 & 80 & 44 & 59 & I6 & $2 I$ & 57 & $76^{\mathrm{b}}$ \\
\hline Cocoa agroforest & 15 & 20 & Io & 13 & 45 & 60 & 29 & $39^{\mathrm{c}}$ \\
\hline $\begin{array}{l}\text { Mulching with AF } \\
\text { species }\end{array}$ & 48 & 64 & 25 & 33 & $4 \mathrm{I}$ & 55 & 48 & $64^{d}$ \\
\hline Woodlot & 4 & 5 & 2 & 3 & 5 & 7 & 4 & $5^{e}$ \\
\hline $\begin{array}{l}\text { Others, } \\
\text { e.g. alley cropping }\end{array}$ & 0 & 0 & I & I & o & 0 & 2 & $3^{e}$ \\
\hline ANOVA results & \multicolumn{8}{|c|}{ F- calculated $=9.8 \mathrm{I}, \mathrm{F}-$ tabulated $(\mathrm{df}-5, \mathrm{I} 8)=2.77$, significant $(\mathrm{P}<0.05)$} \\
\hline
\end{tabular}

Note: values followed with similar superscripts are not significantly different.

Table 4: Level of adoption of agroforestry systems by the respondents in the study area.

A total of $67 \%$ of AF farmers were willing to plant trees and to take care of those already planted (table 5). Despite the fact that this group of people is aware of the ecological, environmental and socio-economic roles of trees and the negative impact of deforestation on sustainable forest resources management, they claimed that trees will constitute hindrance to crop growth and yield. Those that are willing to plant, retain and take care of trees $(67 \%)$, reported the various roles the trees are playing. These include conservation of biological diversity, shade for (young) plants and man, provision of fruits to quench thirst and control of erosion. These roles are essential to man. The species they retained include Milicia excelsa Khaya ivorensis, Celtis zenkeri, Ficus exasperata and Eleas guinensis. However, results of the student t-test show that there are no significant differences ( $p>0.05$ ) in proportion of respondents' willingness to plant or retain trees when compared to those not willing to plant (table 5 ).

The average crop yield on respondents' fields is $750 \mathrm{~kg}$ per annum for farms where $\mathrm{AF}$ is adopted while the value for non-AF farms is $630 \mathrm{~kg}$ (per hectare of land). This directly affected the respondents' income. Mean annual income of crops from AF farms is estimated at twenty-five thousand Naira $\left(\mathrm{N}_{25}, 000\right)$ i.e. \$214 while the amount accruing from non-AF farms is $\mathrm{NI}_{17}$, 000 or $\$ 147$. T-test results reveal that there is a significant difference $(\mathrm{P}<0.05)$ in crop yield and annual average income between agroforestry farms and non-agroforestry farms. 


\begin{tabular}{l|l|l|l|l}
\hline Locations & No & $\%$ & Yes & $\%$ \\
\hline Odigbo & 23 & 31 & 52 & 69 \\
\hline Akoko & 17 & 23 & 58 & 77 \\
\hline Idanre & 15 & 20 & 60 & 80 \\
\hline Akure & 45 & 60 & 30 & 40 \\
\hline Total & I00 & 33 & 200 & 67 \\
\hline t-test results & $\begin{array}{l}\text { t-calculated }=1.82, \text { t-tabulated }(\mathrm{df}-3)=3.18, \\
\end{array}$ \\
& p-value $=0.17$, not significant $(\mathrm{p}>0.05)$
\end{tabular}

Table 5: Willingness to plant trees, retain trees on farmland during cultivation or take care of those planted.

\section{Discussion}

The results of this study show that both males and females are involved in farming activities. However, the percentage of men in agroforestry practice was found to be significantly $(\mathrm{p}<0.05)$ higher than their female counterpart and the difference is highly significant. This is due to the fact that farming in general is usually labour-intensive and requires a lot of energy. It is widely assumed to be, and so is usually regarded as a man's job. Women can only participate in activities that are less strenuous while men are working on the farm. Females' activities include planting of crops, cooking for the family, firewood gathering and collection of NTFPs like fruits and vegetables for family use. These are culturally regarded as the duties of women in the study area. Generally, most of the respondents were mature adults, married (only $4 \%$ across locations were single) and breadwinners.

The highest percent of the total number of respondents are aged between $4 \mathrm{I}$ and 50 years. At this age, men are most active and are duty-bound to provide for their household. Therefore, people in this age group are agile and have found gainful employment in farming, hence their involvement in agroforestry practice. Younger people, especially those younger than 30 years, are usually not found in rural areas. Their level of education notwithstanding, they normally migrate to urban centers such as Lagos, Abuja (the Federal Capital Territory), Port Harcourt or Kano in search of a white-collar job. Some leave for urban centers to take part in politics. The rate of migration from rural to urban centers in Nigeria is now surging upwards. Rural-urban migration began with the discovery of oil in Nigeria. The present oil boom has led to increased wealth in the economy to the extent that people now abandon farming for places where a paid job can be found. Also, the absence of infrastructure and social amenities such as good roads, access to healthcare facilities, safe water, schools and electricity have made rural areas less appealing for young people to stay and earn their living. Rural-urban migration has its peculiar problems. These problems include overpopulation, social vices, congestion and poor environmental conditions.

It is very common to have a big family in Nigeria. A large family is usually desirable in order to supply farm labour and to assist in collecting minor forest products for family consumption. However, family size directly affects biodiversity conservation, environ- 
mental sustainability and food security. A large family size implies the clearing of more forest (where biodiversity is conserved) for arable cropping, encroachment, increase in forest resources exploitation, and burning of more fossil fuel. This has led to deforestation and its subsequent socio-economic, ecological and environmental problems (Adekunle, 2002). Adetula (2008) and Adekunle (2006) reported that the ever-increasing demand for food has resulted in the clearing of tropical rainforests for agricultural purposes by poor farmers and landless people. MAFFR (2007) provided a detailed account of encroachment and its impact on natural forest conservation and biological diversity in Ondo State, Nigeria. According to this government agency, $699 \mathrm{~km}^{2}$ of forestland has been encroached from the total forest reserve of $2753 \mathrm{~km}^{2}(25.4 \%)$ over a period of five years. As a result, several plants and animal species have become extinct while several others are now vulnerable and threatened. Oke (2008) noted that agroforestry can make more food available and at the same time reduce over dependence on the forest.

The educational level of farmers influences the way they use natural resources. Reckless use or abuse could affect the environment. As most of the respondents have not had a formal education, there is the problem of adopting new ideas and technologies, especially AF technology, available from extension agents. It was observed from this study that the major occupation of most of the respondents is farming. This buttresses the fact that the State is an agrarian state. But, land is always in short supply. As a result, agroforestry is a better land use option when compared to the old farming system (fallow and shifting cultivation). The old fallow system is no longer viable and sustainable (Oke and Odebiyi, 2007; Oke, 2008).

Non-availability of land for farming has made the practice of the approved taungya system and other forms of AF system acceptable to landless farmers and non-natives in the study area. Approved taungya is the allocation of land to farmers in forest reserves where tree seedlings and arable crops are planted together (Adekunle and Bakare, 2004). The preparation of the land, its allocation and supplies of tree seedlings are the responsibility of the Forestry Department. Farmers are responsible for planting and caring for the seedlings along with their crops. This type of agroforestry practice is a way of complete utilization of forest soil for improved agricultural production in developing nations. It is an avenue for farmers to participate in tree planting and be directly involved in the afforestation project of the government. Under this system, the cost of afforestation is shared between farmers and the government.

Land allocation under taungya is free while those leased from individual landlords attract compensation from the renters in form of cash, kind or share of crops to the owners. The farmer is expected to vacate the site for another place as soon as the trees begin to close canopy. The size of the respondents' farms revealed that the majority of them have small landholdings (less than four hectares). This is a great hindrance to tree planting and woodlot establishment in the communities considered. Farmers cannot afford to share the little land in their possession between arable cropping and tree planting. As a result, the number of those with woodlots is very low. They prefer a situation where the same land can be used for tree planting and cropping concurrently. This was also found 
by Chawdhurry et al. (2004) who reported that landholding in Bangladesh is generally less than four hectares. In a similar study, Adekunle and Bakare (2004) reported that $87 \%$ of Nigerian farmers usually have a small farm size of between $\mathrm{I}$ and $\mathbf{2}$ hectares. In this study, $83 \%$ have a farm size that varies between one and two hectares while $95 \%$ have between one and four hectares, which is similar to the results of these two studies. It is common for farmers in Nigeria to have their farms separated by a distance of about one kilometer. Moving from one plot to the other makes farming and tree planting cumbersome.

Sixty-four percent of respondents were aware of agroforestry practices. Farmers in the study area usually retain trees deliberately on farmlands during land preparation. This is the most popular agroforestry system in the study area. Other forms of AF practiced by respondents include woodlots and taungya. Because of its complexity and a lack of appropriate species suitable for use in the system,only a few of the respondents are adopting alley farming Seven percent also claimed that there are family, private or community forest/woodlots in their communities. There are, however, significant differences in the level of adoption of these AF systems. While $59 \%$ of respondents are willing to plant trees and also ready to maintain those planted, $74 \%$ deliberately retained trees on their farmlands.

The only species most of the respondents are willing to plant is Tectona grandis. It is a fast growing exotic species with commercial and timber value. Those retained on farmland are tropical indigenous hardwood species such as Triplochiton scleroxylon, Mansonia altissima, Chrysophyllum albidum, Celtis zenkeri, Milicia excelsa, Khaya ivorensis, Afzelia africana, Strombosia pustulata, Treculia Africana, etc. These tree species are deliberately retained by farmers to provide shade and shelter during sunny days, to provide shade to young plants, to control erosion and provide fruits that are edible and/or of medicinal value. Trees retained around streams can protect them from drying out. This corroborates the findings of Oke (2008) that indigenous tree species are deliberately retained on farmland by farmers during land preparation for several reasons. In cocoa agroforests, farmers retain trees to provide shade for young cocoa seedlings after planting. It is also common to find mature trees in old cocoa plantations in Ondo state, Nigeria. Virtually all tree species are used as a source of mulch materials while Gliricida sepium is commonly planted with yam to serve as stakes.

Some of the reasons why some respondents are not willing to plant trees include non-availability of land as the majority has a small landholding, problems with land tenure, long gestation period of trees, lack of planting materials (seeds and seedlings), lack of technical expertise, lack of incentive and poor government policies. Rural communities condemn the act of tree planting. Trees, according to them, are a free gift of nature that cannot be exhausted. This attitude explains why forestry is abused and overused without the environmenbtal consequences of such actions being taken into account. In addition, land under lease can only be used to grow temporary crops such as cassava, maize, yam, cocoyam, etc. Landowners do not allow the planting of permanent crops (trees). 
Agroforestry has the potential to increase food production and at the same time, the tree components could serve so many essential environmental roles. Therefore it can be viewed as a good multiple land use system. Various authors (Adekunle et al, 2005, Adedire, 1999, Daily, 1997) have reported on the potential of agroforestry.

\section{Conclusion and recommendation}

This study examined the contribution of agroforestry systems to environmental conservation and sustainable agricultural production in Ondo state, Nigeria. The practice of agroforestry in the study area is fundamentally due to the presence of people without farmland, availability of fertile land under forest cover, population growth leading to an increase in demand for food and forest products. The ecological, economic and environmental roles of well-planned agroforestry for rural livelihood and sustainable development are numerous. Agroforestry could prevent deforestation and its complications, and make more trees available for local consumption and sale. It also has the ability to resolve conflicts among various land users as a multiple land use system.

Since the majority of the farmers are willing to plant and retain trees, and take care of those planted, they should be encouraged by the government to do so. Seedlings and seeds should be distributed to farmers. Those taking care of planted trees should be compensated (e.g. cash reward or tax exemption), while government policies not in favour of tree planting should be amended and better ones promulgated. Tree growers should be entitled to the (by-) products of what they plant on their farmlands. Incentives and loans should be given to those willing to plant trees. Farmers under the government-approved taungya should be duly rewarded and encouraged by the Forestry Department. Social amenities such as safe water, schools, health centers, good roads and electricity should be provided in the rural areas. More people might thus be willing to reside in the rural areas and engage in farming and tree planting. As a result this could reduce the present rate of rural-urban migration.

\section{References}

Achard, F., Eva, H.D., Stibig, H., Mayaux, P., Gallego, J. Richards, T. and Malingreau, J. (2002). Determination of deforestation rates of the world's humid tropical forests. Science 297: 999-1002.

Adedire, M.O. (1999). The concept and definition of agroforestry. Paper presented at DSO/ICRAF - HULWA Regional Training of Trainers Course in Agroforestry for Sustainable Agricultural Land use and Natural Resources Management. Kumass, Ghana.

Adedire, M.O. (2004). Environmental Protection: The Agroforestry Option. Nigerian Journal of Forestry 34 (I): $\mathrm{I}-6$.

Adekunle, V.A.J. (2002). Inventory Techniques and Models for Yield and Tree Species Diversity Assessment in Ala and Omo Forest Reserves, S. W. Nigeria. Ph. D. Thesis, Federal University of Technology, Dept of Forestry and Wood Technology, Akure, Nigeria, $179 \mathrm{p}$.

(2005). Trends in Forest Reservation and Biodiversity Conservation in Nigeria. In: Environmental Sustainability and Conservation in Nigeria, Okoko, E., Adekunle, V.A.J. \& Adeduntan, S.A. (Eds), Environmental conservation and Research Team, Federal University of Technology, Akure Nigeria, 82-90. 
(2006). Conservation of Tree Species Diversity in Tropical Rainforest Ecosystem of Southwest Nigeria. Journal of Tropical Forest Science (Malaysia) 18(2): 91-10I

Adekunle V.A.J. \& Bakare, Y. (2004). Rural Livelihood Benefits from Participation in Taungya Agroforestry System in Ondo State Nigeria. Journal of Small-Scale Forest Economic, Management and Policy 3(I): 131138.

Adekunle, V.A.J., Dafiwhare, H.B. \& Ajibode, O.F. (2005). Microbial population and diversity as influenced by soil $\mathrm{pH}$ and organic matter in different forest ecosystems. Pakistan Journal of Biological Science 8 (I0): 1478-1484.

Adetula, T. (2008). Challenges of Sustainable Forest Management in Ondo State: Community Based Forest Management System as a Panacea. In: Research for development in forestry, forest products and natural resources management, Onyekwelu, J.C., Adekunle, V.A.J. and Oke, D.O. (Eds.), Proceedings of the ist National Conference of the Forest and Forest Products Society held at the Federal University of Technology, Akure, Nigeria, 16th - 18th April, 2008, 242-247.

Atolagbe, A.M.O. (2002). Architecture in Nigeria and the practice for sustainable development: A comparative study of modern and indigenous housing strategy. AARCHES Journal 2 (I): 6I-65.

Chawdhurry, Q., Rashid, A.Z.M. \& Afrad, M. (2004). Socio economic significance of Reed Forest in a rural community: A case study from the greater Sylhet Region of Bangladesh. Journal of Small-Scale Forest Economic, Management and Policy. 3 (I): I2I - 130.

Daily, C. (1997). Nature sciences: Societal dependence on natural ecosystems. Island press, Washington DC, USA.

Intergovernmental Panel on Climate Change (2007). Summary for Policymakers. Climate Change 2007. Impacts, Adaptation and Vulnerability. Contribution of Working Group II to the Fourth Assessment Report of the Intergovernmental Panel on Climate Change (PDF), Cambridge University Press, Cambridge, UK, 7-22.

Leakey, R. (1996). Definition of Agroforestry revisited. Agroforestry Today 8(I): 5-7.

Lundgren, B. (1982). The use of agroforestry to improve the product of converted tropical land. Paper presented for the office of Technological assessment of the United State Congress. ICR miscellaneous papers ICRAF, Nairobi.

- (1987). ICRAF's first ten years. Agroforestry Systems 5(3): 197-218.

McNally, R., Ballinger, A. \& Horrocks, G. (2002). Habitat change in River Red Gum Floodplains: Depletion of Fallen Timber and Impacts on Biodiversity. Victorian Naturalist, Volume II9(4), 107-113.

MAFFR (2007). Report of the Technical Committee on the Encroached Areas in the State's Forests Reserves, Ministry of Agriculture, Fisheries and Forests Resources, January 2007, 31 p.

Mundi, N.E. (2005). Environmental issue in Nigeria. In: Okoko, E., Adekunle, V.A.J. \& Adeduntan, S. A. (eds). Environmental Sustainability and Conservation in Nigeria. Environmental Conservation Research Team 30-32.

Oke, D.O. (2008). The Changing Cocoa Agroforests of Ondo State, Nigeria: Implications for Environmental Stability, Food Security and Biodiversity Conservation. In: Research for development in forestry, forest products and natural resources management, Onyekwelu, J.C., Adekunle, V.A.J. and Oke, D.O. (Eds.), Proceedings of the Ist National Conference of the Forest and Forest Products Society held at the Federal University of Technology, Akure, Nigeria, 16th - 18th April, 2008, 60-63.

Oke, D.O. \& Odebiyi, K.A. (2007). Traditional cocoa-based agroforestry and forest species conservation in Ondo State, Nigeria. Agriculture, Ecosystems and Environment, 122: 305-311.

Okojie, J.A. (1996). Once Upon a Forest: A Masterpiece of Creation. UNAAB Inaugural Lecture Series No. I, 29 p.

Salami, A.T. (1998). Vegetation Modification and Man-induced Environmental Change in Rural Southwestern Nigeria. Agriculture, Ecosystem and Environment, 70: 159-167. 
Ranasingbe, D. M. \& Abayasiri, S. (2008). Forestry Education and Global change: a case study on the contribution offorest plantations in Sri Lanka as an adaptation measure to climate. In: New perspectives in forestry education, Temu, A. B., Chamshama, S. A. O., Kung'u, J., Kaboggosa, J., Chikamai, B. and Kiwia, A. (Eds.), Peer review papers presented at the Ist Global Workshop on forestry education, Sept 2007. ICRAF, Nairobi, Kenya.

UNEP (2006). (United Nation Environmental Programme). Africa Environment Outlook 2: Our environment, Our wealth. UNEP Job No. DEW/08o1/NA 542 p. 